\title{
CORPORATE IDENTITY IN THE BRAND CO-CREATION ERA
}

\author{
AUTORES: MONFORT, Abel; SEBASTIÁN, Ana and LÓPEZ, Belén \\ PhD - Centro Universitario Villanueva - España - amonfort@villanueva.edu \\ PhD - Universidad de Valladolid - España - anaseb@hmca.uva.es \\ PhD - ESIC, Business \& Marketing School-España-belen.lopez@esic.edu
}

\begin{abstract}
The following text analyzes corporate identity from a dynamic perspective. Its aim is to know if brands turn corporate values into behaviours that meet stakeholders' expectations. Firstly, the essay explains how corporate identity is a key concept in the management of intangible assets because it can generate brand value and reputation. In order to explain this point, authors underline best practices in managing corporate vision and values. Secondly, the paper explores content and communication platforms used by corporate and commercial brands. Lastly, the text sets out how brands should develop a dialogue and co-creation between company and stakeholders, generating consumer participation.
\end{abstract}

Listening to stakeholders and offering them a dialogue platform allows companies to obtain insights about its behaviours and expectations. Therefore, brands can offer relevant and accurate products, experiences and content to its stakeholders. Managing brand identity from a co-creation point of view creates differentiation and competitiveness. Nevertheless, it presents a set of challenges, especially when companies have to choose between the expectations of the stakeholders and the corporate identity.

\section{Key Words}

Corporate identity, corporate reputation, corporate social responsibility, corporate culture, social media, intangible asset management.

\section{What is corporate identity and why is it important for companies to connect in a real way with their publics?}

When we speak of identity, we are referring to a set of corporate values, vision, believes and design (Balmer \& Gray, 2003; Hatch \& Schultz, 2010) that are embodied in the corporate brand by verbal and visual expressions that imply a certain business behaviour (Knox \& Bickerton, 2003). The literature emphasizes the need to establish a bond between stakeholder's expectations, which arise from the communication of one's identity, and the real experience of the company's publics when they relate to the brand (Alloza, 2001).

Corporate identity is important for the relationship with stakeholders because it guides the behaviour of all the organization's members and, hence, gives visibility to the value they contribute to the company and to the attributes by which the company is recognized both internally and externally. Consequently, when a certain public of interest comes closer to the company, the experience of that relationship should rest on the principles of identity. Corporate identity can be represented by different symbols (logotypes, colours, smells, corporate music, etc.) that stimulate memory of the brand identity's promise in the mind of stakeholders.

In short, corporate identity is what the company says about itself. This self-description is not a static 
concept: it must be coherent and it must manifest itself in the company's behaviour, as in the experiences it provides to its publics. The strategic concept that defines identity is the corporate vision that will serve as a guide to enable stakeholders to distinguish one company from another and, therefore, yield the desired differentiation from the competition. It must be emphasized that the corporate brand and its identity is differentiation and the sense of belonging (Hatch \& Schultz, 2003, 2010) and it affects both employees and other stakeholders.

As noted above, the corporate vision is decisive, as this vision is the vehicle through which management's aspirations for the company are expressed (Hatch \& Schultz, 2001). That is, it is a verbal formulation - which becomes real in the company's behaviour in all spheres - that reveals the company's intentions for the future (Sanz, 2005). In sum, the corporate vision is the "guiding thread that links all employees and, ideally, other stakeholders as well, as they can identify with it and share it with others" (Argenti, 2014:188). That is, the objective of a good identity will express itself in communicative terms, as the business goal in approaching media "will be to generate earned media -not what we say about ourselves, but what others say about us" (Arthur Page Society, 2012:13). Having others say good things about us will depend on whether what we say about our company (identity) links up with the publics' expectations and, as a result, they want to "share our beliefs".

An example of this process between identity and communication can be found in a company's commitment to its employees. A satisfied employee is a communication agent who can transform corporate identity into a positive external image. This is attested to by Great Place to Work, a service for the assessment of working cultures that measures the relationship between the view of employees and of leaders. In this system, an employee will consider a workplace to be excellent when there is trust and enjoyment of the persons you work for and, you feel pride in what you do. Moreover, a leader considers a workplace to be good if the space is conducive to attaining the objectives of the organization by means of teamwork in an environment of trust, and where employees give the best they have to offer. This process of cohesion between the aspirations of the former and of the latter must be based on a shared common identity. In 2015, according to this organization, the five best companies to work for in the world are: Google, SAS Institute, W.L. Gore \& Associates, NetApp and Telefónica (Great Place to Work, 2015).

Although corporate identity relates mainly to the corporate brand, the fact is that good management of the corporate brand will add value to all the services and products (Ind, 1997). Thus, in the last instance, commercial brands should also be steeped in the guiding principles set forth by the corporation, beyond the structure of relations between the company and its commercial brands: that is, independently of what the literature calls the brand architecture (Aaker, 2004).

Nevertheless, by managing a brand on the basis of identity, one may have the impression that relationships with publics and the construction of a corporate reputation should not be very complicated. Ultimately, if an identity implies behaviour and, consequently, recognition among the publics, it may appear that the process will move in a coherent direction. However, this process is not linear, as it demands that aspirations be treated across all departments. Moreover, as we shall see, publics' expectations can be contradictory, making their management somewhat complex.

For example, if we examine the corporate vision of a major Spanish multinational bank, we will read the following: "our vision is to become the best commercial bank, winning the trust of our employees, customers, shareholders and society at large". And then, it gives details on the concrete form this declaration of intentions takes with each of the stakeholders mentioned in the vision. For customers and building trust, they state that they must offer them "simple, personalized solutions, fair and equitable treatment, and excellent service in our offices and digital channels, with the aim of increasing their satisfaction and loyalty to the Bank". That is, the corporate brand, in its quest for transversality in identity, would have to achieve a final customer 
experience that accords with the aspirations expressed in the declaration of intentions (offices, call centres, virtual office, newsletter, etc.). Besides the departments charged with working in this direction with customers, work must be carried out in other areas of the company to replicate this identity with shareholders, workers and society at large. It also may be the case that what shareholders want is the opposite of what customers want.
The corporate brand department does not have sufficient power to manage all such behaviours or areas that contribute to building trust. "Others", by monitoring identity, will enable the organization to steer itself in the same direction. These are the socalled departments for the management of intangible business assets. Grasping such assets' relationship with identity is fundamental for understanding the difficulty of relations between the company and its stakeholders.

\section{How does brand identity integrate into management of intangible assets?}

All prior development of corporate identity is decisive for the building of intangible business assets. At present, more than $80 \%$ of the companies' market value lies in their intangible assets. This is set forth in reports such as those in the latest "Manual on Corporate Social Responsibility for Directors" (Fundación Seres and KPMG, 2015) or the better known "Annual Study of Intangible Asset Market Value" issued by Ocean Tomo annually. The latter reveals that the market value added by intangible assets to S\&P 500 companies amounted to $84 \%$ in 2015, having shown a substantial upward trend since 1975 .

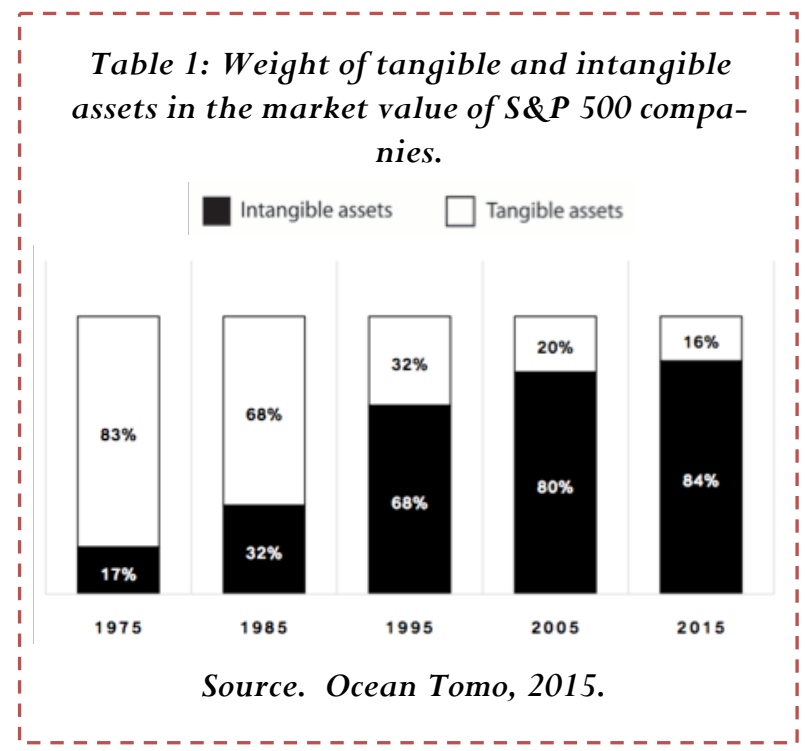

These figures underline the importance of appropriate management and reflect the role played by professional staff in charge of managing and leading departments such as corporate brand, social responsibility, culture or corporate reputation. Good management of these areas will foster a bond be- tween the company and publics, while enhancing differentiation and the sense of belonging.

In this process, the emergence of the new technologies involves both great opportunity and risks for organizations to develop powerful instruments for listening and dialogue capable of building a good brand image based on the organization's identity. Nevertheless, it has also made it difficult to maintain the essence of the company in a setting marked by a continuous flow of information from social networks.

In the social sciences, special importance is assigned to corporate reputation, the corporate brand, corporate social responsibility (CSR) and corporate culture as key intangible assets. These are all deeply linked to the brand identity, as their credibility and development will be marked by the attributes defined in the identity: "who I am" and "where I am going". All these must be interconnected, and thus lend coherence to the company's work with its stakeholders.

One of the fundamental intangible assets is the brand. As we have argued, the corporate brand department directly works on building and defending the company identity. The literature holds that good management of the institutional brand helps publics understand what a company is and what it hopes to be (Schultz \& de Chernatony, 2002). This process is carried out through brand management and will have consequences in every point discussed in this paper. That is, if you want to connect with your publics, you first need to know who you are 
(identity), be able to listen to your publics and, lastly, know how to convey who you are. It is here where tensions arise between what you say you are and what is expected of you.

However, the corporate brand is not an intangible asset that acts in isolation and with no interest in the formation of synergies. Along with the brand, other intangible assets can represent corporate work which, in the final analysis, takes the form of communication and a sense of belonging. The department of corporate social responsibility merits special consideration.

CSR is a corporate commitment to sustainability that takes into account stakeholder expectations in this field and aims to create economic and social value (Lindgreen et al., 2012; Windsor, 2006). CSR bases its strategy on the triple bottom line, a multi-dimensional strategic approach that encompasses both shareholder interests and the environmental and social result (Elkington, 1997). De la Cuesta (2004) argues that the policies of the CSR department must be the central pillars of the entire business strategy. The CSR department will have a relationship with the corporate brand area because a company that wants to be socially responsible must align its identity with its CSR commitment (Villagra \& López, 2013).

Nevertheless, companies' motivations for incorporating this model of business management are diverse. These include, in allusion to instrumental reasons (Lopez \& Fornes, 2015), the fact that CSR also has a direct relationship with other business intangible assets: identity, image, culture, corporate brand, reputation and communication (Gray \& Balmer, 1998). Therefore, intangible assets must all, jointly, be integrated in the company's strategy and they must be managed from a common perspective for the company to be credible to stakeholders.

Another of the intangible assets that must be aligned with a corporate brand-based identity is the corporate culture. This department, according to Schein (1984), seeks to institute patterns of behaviour in employees through a learning process that will take account of research, discovery and development of guidelines for integration and adaptation inside and outside the company. Culture can become a competitive edge when these internal patterns are valuable, different and inimitable (Barney, 1986). In this respect, Highhouse et al (1999) hold that good corporate culture will make the company a good place to work provided it is perceived as respectable, and a space that fosters an appropriate professional environment. Corporate culture also must also take into account the company's identity and the way in which it communicates with workers (Hatch \& Schultz, 2003). That is, the pattern to be inculcated in ways of working and ways of being an employee must be based on what the company is and what it wants to become. When consistency is achieved, the employees become a link between the internal dimension (identity) and the external dimension communication that strengthens brand construction (Harris \& de Chernatony, 2001).

The corporate culture is made possible by eagerness, enthusiasm, teamwork, loyalty, etc. That is, by the most human part of an organization's employees. On this basis, individuals can find meaning in their day-to-day activities. Bill Gates once said that his biggest success at Microsoft was to surround himself with excellent teams (Sebastián \& López, 2009: 110).

Table 2 below shows how corporate identity completely influences the development and functions of departments of culture, brand and corporate social responsibility. Guided by the company's declaration of intentions (identity), these departments' actions must safeguard the linkage between what the company says it is and how it behaves. When this process is a reality, it is conveyed to publics in an orchestrated manner through corporate communication. Communication will seek recognition based on the desired identity. The consequence is the garnering of a reputation, in view of the fact that intangible assets are measured by indicators used to evaluate an organization's reputation: work with employees and CSR policies, among others. 
Table 2: Ensemble of relations between different business assets.

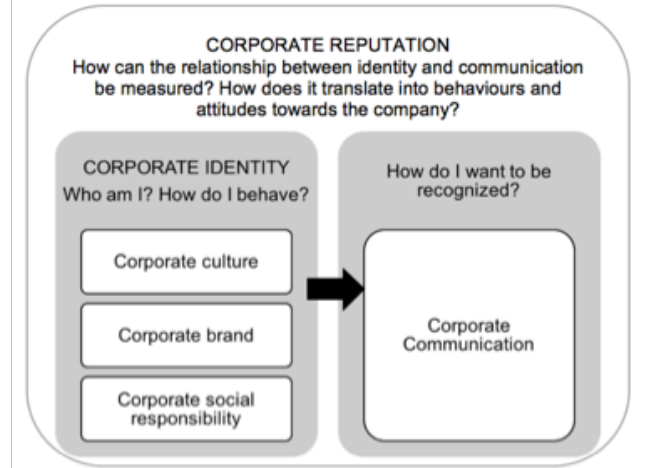

Source. Own elaboration.
It is no wonder that this reputation is growing in importance for, ultimately, its aim is to "tangibilize" all intangible assets. The Reputation Institute (2013), a leading consultancy in business reputation, emphasizes that the foundation of a system of business management is the corporate identity itself (integration of the corporate mission, definition of stakeholders and alignment). Nevertheless, it also points to the following as focal points of action: corporate strategy and intelligence (metrics and evaluation of stakeholder expectations), management and accountability and, lastly, integration in the company's development of stakeholders' expectations through initiatives that seek to represent the identity of the company beyond its products or services. To do so, narrative discourses are generated in all points of contact, along with management of brand ambassadors, and even in the company's way of doing business.

Aside from the self-attributions that many organizations may engage in, it would seem useful to ensure that one's reputation stands as an umbrella for the company's other intangible assets. This is especially due to its eagerness to measure the development of competences of the different areas. In any event, the anchor that keeps reputation measurement from going adrift is the sustenance of a powerful corporate identity that helps the company discern the difference between that it "is" and what it "is recognized" as. Without a clear idea of what a company says it is, it is quite difficult to usefully measure the conduct and perceptions of other stakeholders.

As we have seen, the corporate identity falls within the domain of the institutional brand department. However, the cross-cutting nature of identity affects the development of aspects of CSR, corporate culture and the measurement of corporate reputation. In principle, when all these departments act in alignment, communication should occur, with the issuance of messages that can convey everything that is being done and on the basis of the organization's "who we are". That is why the brand identity is conveyed through communication techniques and platforms. Such communication generates a promise among stakeholders. an improvement in the business products and services, to cite only a few (Carreras et al., 2013). 
So far, we have discussed the theory of managing intangible assets and the impact of identity. However, in the era of social networks and of bidirectional discourses between companies and publics, it is essential to know how companies enter into a relationship with their publics and listen, incorporate, explain their raison d'être, their positioning, the products they launch and the experiences they offer. This entire process is what we call stakeholder dialogue. Good management of these conversations can enhance reputation (measurement of the development of intangible assets). However, a failure to listen can cause a real reputational crisis that will affect the organization's development. For this reason, once the brand identity has been defined, the company adopts a building plan based on communication (Aaker \& Joachimsthaler, 2004), for "communication is, perhaps, one of the most important forms an organization has to influence the corporate image among its publics" (Capriotti, 2007:53).

\section{Is social media being used adequately in brand co-creation?}

In principle, it might appear that, with the number of means available to companies, brand co-creation processes should be simple. However, this is not the case. Companies are encountering difficulties in knowing what the expectations of their stakeholders are and, even worse, when they find out what the expectations are, they do not always respond to them. Throughout the process of identity dissemination, a priority must be given to multiple tools and not only advertising, as the latter "plays only a minor role in this process" (Aaker \& Joachimsthaler, 2004:58).

As we shall now see, the problem that arises in these processes is to be able to maintain the identity of the company and also to incorporate stakeholders' expectations. That is, such needs must be integrated without renouncing the essence of the company. Moreover, the very notion of a "multistakeholder" approach also presents a certain degree of complexity. What happens if what one stakeholder expects is entirely different from what another expects? Dialogue offers solutions, but also certain complexities.

As we have seen, identity is a response to a company's question: who I am (identity attributes), what is my purpose (mission and vision) and where do I want to go (strategy). When a company knows where it is going, it can relate to its publics from a stable position. That is, it can listen, and be listened to, based on guiding principles. Hence, "coherence and unity will enable... [...] us to speak of an implied dialogue between the organization (which presents an identity) and the stakeholders, who will respond in the form of favourable or unfavourable attitudes towards the company" (Monfort, 2014:194).

Bajo (2015:93) argues that the origin of the dialogue is as follows:

The company will not be able to meet the expectations of all groups at the same time, especially if one group comes into a direct conflict with another, and even with the very objectives of the organization. In such a case, the company is facing what is called a dilemma [...]. To resolve an ethical dilemma - a conflict that affects different people - a conversation should be initiated to find an optimal solution for all, including the organization itself.

Underlying this statement is the concept that has recently become known as brand co-creation. One of the precursors for the development of the cocreation concept is C.K. Prahalad, who defines it as follows:

Companies can no longer act autonomously, designing products, developing production processes, crafting marketing messages, and controlling sales channels with little or no interference from consumers. Consumers now seek to exercise their influence in every part of the business system. Armed with new tools and dissatisfied with available choices, consumers want to interact with firms and thereby co-create value. The use of interaction as a basis for co-creation is at the crux of our emerging reality (Prahalad \& Ramaswamy, 2004:5).

Although this perspective involves a very productcantered approach, it can still be applied to corporate identity and, therefore, to all the relations be- 
tween the company and its stakeholders through dialogue and management of intangible assets. Indeed, Kotler et al. (2012:50) contend that cocreation processes should entail three necessary steps that very well could be adjusted for relations with investors, employees, the community, etc: 1) the creation of a platform as a generic product that can subsequently be customized, 2) assisting customers to adopt the platform according to their needs, and 3) asking for an opinion on the experience of products, thus enriching the platform with the personalization effort made by consumers. As we may observe, such initiatives could be replicated in the company's relations with all its stakeholders. That is, the creation of platforms for dialogue and co-creation with different stakeholders.

An example of co-creation is the initiative in social media of the international coffee company Starbucks: Share. Vote. Discuss. See. The company has a profile in different social media (Facebook, Twitter and Foursquare, among others). We would also note the creation of the website called My Starbucks Idea. On this website, consumers and followers of the brand have been contributing to the generation of new ideas on products and rating the submissions of other consumers since 2008. In this way, the company gains in-depth knowledge of its customers through their comments (Chua \& Banerjee, 2013). These ideas translate into figures: the company has implemented more than 1,000 ideas arising from its conversation with consumers. All information at www.mystarbucksidea.com.

Another example is Social Noise and Sony Pictures Spain, who sought out a partnership with the most important YouTubers in the country in order to create a cinema experience in the form of film shorts to promote the most high-profile feature film premieres, generate traffic to the distributor's social networks and foster movie attendance. They created the first fiction format of a brand with YouTubers that was sustainable over time for all the distributor's future premiers: "La otra película" [The Other Movie]. The core of this formula involves the periodic production of cinema-quality shorts of some 10 minutes related to current Sony Pictures movies, starring YouTubers of great prominence for the target. The first edition of "The Other Movie" was launched for the premier of Fury. Only twentyfour hours after its launch, Fury. The Other Movie achieved more than 790,000 views, more than 80,000 likes and nearly 100,000 comments. Publication of the video in Twitter, redirecting to the YouTube video attained an interaction rate of $285 \%$ of the profile average. Analysis of the social conversation on this first edition reveals more than 3,500 organic mentions of Sony and of "The Other Movie" in the first two months following the launch. In short, a major success of creation of a significant audiovisual experience for an age group that is wary of going to traditional cinemas (Asociación Española de Anunciantes, 2015: 231-240).

The third case of co-creation to be discussed is the successful Christmas Lottery campaign of 2014. The "Gordo" lottery prize represents a sentiment in the collective imagination that, for many years, has been associated with the Christmas spirit in Spain. The results of the communication strategy of 2014 show the power of emotional communication to change people's behaviour towards a brand. As a result of falling sales in recent years due to the economic crisis, this campaign cantered on conveying the value of sharing the prize with others. The aim was to re-establish people's identification with the prize. The results were as follows: 8 million views on YouTube, 3 consecutive days as a trending topic in Spain, 7.4 million euros of media impact, and 110 million euros more in sales than in 2013. And more than 5 million parodies in diverse media. In short, it is, to date, the most viral campaign in the history of advertising in Spain, winning the Gold Award in Effectiveness in commercial communication of 2015, and also winning the following awards, among others: El Sol Festival, Gran Premio TV. 1 Oro TV/1 Bronze Branded Content/ 1 Bronze Cyber microsite (Asociación Española de Anunciantes, 2015: 75-92).

To achieve an in-depth understanding of the reasons for the success of such initiatives by brands in using virality, monitoring of publics and the continuity of conversations they generate mainly in online media, we present some of the conclusions of recent research in which we have taken part. The latter in- 
volved qualitative research in the framework of a national $\mathrm{R}+\mathrm{D}+\mathrm{i}$ research project approved by the Ministry of Economy. Although the question of online dialogue was treated only tangentially in the first phase, a series of aspects have emerged that we can discuss, for they usefully illustrate the difficulties of knowing how to adapt the brand identity to the listening and dialogue with stakeholders, and to the aspiration to co-create with stakeholders, as is now being done by a significant number of global and local companies. In a group of experts in different communication disciplines, we found the following statements related to the digital world:

- Brands have to achieve closer contact with their customers by means of active listening. The objective is to identify needs and ways of thinking.

- Advertising communication must take account of what stakeholders are saying, how they are answering and reacting to our messages.

- Online communication does not mean generating content mechanically. Relevant content must be generated that is capable of capturing the attention of saturated targets.

- An essential part of listening is locating the new opinion leaders (YouTubers, bloggers, Instagrammers).

- The information circulating online is not only the information generated by the company, but also opinion information of publics and the comments they generate. Publics complete and ground the brand message. Without them, there are no messages.

\section{What effect does dialogue generate from the perspective of identity?}

This paper has emphasized the importance of brand identity in improving the perception of the company's publics, and to differentiate and manage intangible assets. It is indispensable because it helps generate trust and achieve closer contact with stakeholders, and because identity comprises attributes that are the essence of the brand and allows companies to offer a unique and unrepeatable experience.

Adequate management of identity must be achieved in order to carry out actions that will reach stake-
- The brand's positioning is now based on its contribution to people's life.

This brief overview of the state of the question, presenting the need to manage strong identities while integrating listening and dialogue with stakeholders, provides a useful snapshot of the difficulties encountered in the management of intangible business assets. First, the company must be aligned and, by means of a well-defined corporate essence, must make progress in CSR, branding, culture, and reputation, guided by identity principles. In addition, companies that wish to strengthen their differentiation must engage in a conversation that integrates the discourse of publics that takes into account the opinion leaders in current-day society.

This is the dilemma currently faced by companies in Spain. The debate about the integration of expectations and the defence of a single identity is ongoing. Meanwhile, the public is spending ever more time in their lives in the social networks ( 4 and a half hours/week in Facebook, 3 hours and 45 minutes/week in Spotify, 3 hours 34 minutes/week in YouTube and 3 hours and 9 minutes/week in Twitter, according to the Sixth Study of Social Networks Spain VI [Estudio de Redes Sociales España IAB], 2015). Users use social networks to express opinions on politics and entertainment, but also to share comments and experiences with brands. The issue, then, is to find a midway point between what the company wants and what publics expect. holders through relevant messages that can capture publics' attention. The majority of their communication is online and bi-directionally, and such actions must incorporate global communication strategies to generate open conversations seek active dialogue with publics.

The importance of communication strategies in brand management is undeniable, but companies must take into account their publics by listening to and engaging in dialogue with their stakeholders and 
devoting special attention to the brand experience with the idea of "being" in order to "be recognized".

It is important for brands to include a dialogue with all stakeholders and identify the new opinion leaders. Consumers, through their participation, define companies' role: hence, co-creation and personalization characterize the new relationship between these actors. Companies reflect the importance of generating dialogue because they have realized that the information moving around out there is not only the company's own information, but what publics think and the content they generate. This is how they achieve more notoriety, credibility and trust, as the publics are spokespeople for brands.
However, it is fundamental for brands to engage in dialogue and co-create on the basis of identity: but one of the problems they often encounter is that they do not know how to do this. So brands have to find a way to talk to stakeholders and learn to listen to them, but they must do so carefully, because they might fall into the trap of identity volatility and a situation where they want two things that are diametrically opposed.

In order to articulate adequate management of identity, brands must actively listen to their publics. They must know how to answer and react to their messages in order to generate relevant content, and they must be able to capture the attention of their stakeholders.

\section{References}

- Aaker, D. A. (2004), Brand Portfolio Strategy. New York: The Free Press.

- Aaker, D. A., \& Joachimsthaler, E. (2004). Liderazgo de marca. Bilbao: Deusto.

- Alloza, Á. (2001). La gestión estratégica de la marca. In J. Villafañe (Ed.), Informe anual 2001. El estado de la publicidad y el corporate en España y Latinoamérica (pp. 207-269). Madrid: Pirámide.

- Argenti, P.A. (2014). Comunicación estratégica y su contribución a la reputación. Madrid: LID.

- Arthur Page Society (2012). Building belief: a new model for activating corporate character \& authentic advocacy. Retrieved from http://www.awpagesociety.com/wpcontent/uploads/2012/03/Building-BeliefNew-Model-for-Corp-Comms-2012.pdf

- Asociación Española de Anunciantes (2015). Resultados. La comunicación que funciona. Los casos ganadores de la XVII edición de los premios a la Eficacia en la Comunicación Comercial. Madrid: AEA, Scopen y Plataforma Editorial

- Bajo, A. (2015). El diálogo empresastakeholders como fundamento del reconocimiento empresarial. In J. Benavides y A. Monfort (Coords.), Comunicación y Empresa Responsable (pp.91-120). Barañáin (Navarra): EUNSA.

- Balmer, J.M.T., \& Gray, E. 2003. Corporate Brands: What are they? What of them? European Journal of Marketing, 37, 972-997.
- Barney, J. B. (1986). Organizational culture: can it be a source of sustained competitive advantage?, Academy of Management Review, 11(3), 656-665.

- Caprioti, P. (2007). Planificación del perfil de identidad corporativa para marcas globales. In P. Capriotti (Ed.), Gestión de la marca corporativa. Buenos Aires: La Crujía.

- Carreras, E., Alloza, Á., \& Carreras, A. (2013), Corporate Reputation. Madrid: LID.

- Chua, A. \& Banerjee, S. (2013). Customer knowledge management via social media: the case of Starbucks. Journal of Knowledge Management, 17(2), 237-249.

- De la Cuesta, M. (2004). El porqué de la responsabilidad social corporativa. Boletín Económico Del ICE (Información Comercial Española), 2813, 45-58.

- Elkington, J. (1997). Cannibals with forks. Gabriola Island: New Society Publishers.

- Freeman, R.E. (1984). Strategic Management. A stakeholder approach. Boston: Pitman Ballinger.

- Gray, E., \& Balmer, JMT (1998). Managing corporate image and corporate reputation. Long Range Planning, 35(5), 695-702.

- Great Place to Work (2015). Las mejores multinacionales para trabajar en el mundo. Retrieved from http://www.greatplacetowork.es/mejoresempresas/las-mejores-multinacionales-para-trabajaren-el-mundo/la-lista / 
- Hatch, M. J., \& Schultz, M. (2001). Are the strategic stars aligned for your corporate brand? Harvard Business Review, 79(2), 128-134.

- Hatch, M. J., \& Schultz, M. (2003). Bringing the corporation into corporate branding. European Journal of Marketing, 37(7), 1041-1064.

- Hatch, M. J., \& Schultz, M. (2010). Esencia de marca. Madrid: Lid.

- Highhouse, S., Zickar, M. J., Thorsteinson, T. J., Stierwalk, S. L., \& Slaughter, J. E. (1999). Assessing company employment image: an example in the fast food industry. Personnel Psychology, 52, 151-172.

- IAB (2015). VI Estudio Redes Sociales de IAB Spain. Retrieved form http://www.iabspain.net/wpcontent/uploads/downloads/2015/01 / Estudio_Anual_ Redes_Sociales_2015.pdf

- Ind, N. (1997). The corporate brand. Nueva York: New York University Press.

- Knox, S., \& Bickerton, D. (2003). The six conventions of corporate branding. European Journal of Marketing, 37(7), 998-1016.

- Kotler, P., Kartajaya, H., \& Setiawan, I. (2012). Marketing 3.0. Madrid: LID.

- $\quad \mathrm{KPMG}$, \& Fundación Seres (2015). RSE. Manual para consejeros. Retrieved form http: / / www.kpmg.com/ES/es/ActualidadyNo vedades/ArticulosyPublicaciones/Documents/r se-consejeros-completo.pdf

- $\quad$ Lindgreen, A., Xu, Y., Maon, F., \& Wilcock, J. (2012). Corporate social responsibility brand leadership: a multiple case study. European journal of marketing, 46(7/8), 965-993.

- Lopez, B., \& Fornes, G. (2015). Corporate social responsibility in emerging markets: case studies of Spanish MNCs in Latin America. European Business Review, 27(2), 214 - 230.

- Monfort, A. (2014). La identidad de marca como motor del diálogo legitimador de la actividad empresarial. In N. Villagra y A. Bajo (Eds.), Nuevos diálogos y relaciones entre la empresa y la sociedad: memoria académica curso 2013-2014. (pp. 185-200). Madrid: Universidad Pontificia Comillas.

- Ocean Tomo (2015). Annual Study of Intangible Asset Market Value from Ocean Tomo, LLC. Retrieved from http: / /www.oceantomo.com/2015/03/04/20 15-intangible-asset-market-value-study/

- Prahalad, C. K., \& Ramaswamy, V. (2004). Cocreating unique value with customers. Strategy \& leadership, 32(3), 4-9.

- Reputation Institute (2013). Making the Grade when Stakeholders Rule. 2013 Annual Reputation Leaders Survey. Retrieved from http: / / www.reputationinstitute.com/thoughtleadership/white-papers\#forms.

- Sanz, M. Á. (2005). Identidad corporativa: Claves de la comunicación empresarial. Madrid: ESIC.

- Schein, E. H. (1984). Coming to a New Awareness of Organizational Culture, Sloan Management Review, 25(2), 3-16.

- Schultz, M., \& de Chernatony, L. (2002). Introduction the challenges of corporate branding. Corporate Reputation Review, 5(2), 105.

- $\quad$ Sebastián, A., \& López, B. (2009). Cultura corporativa. In J. Sánchez \& T. Pintado (Ed.), Imagen corporativa. Influencia en la gestión empresarial (pp.105-137). Madrid: ESIC

- Villafañe, J. (2013). Propuesta para una teoría de la reputación corporativa. La buena empresa. Madrid: Pearson.

- Villagra, N., \& López, B. (2013). Analysis of values and communication of the responsible brands. Corporate brand strategies for sustainability. Communication \& Society, 26(1)

- Windsor, D. (2006), "Corporate social responsibility: three key approaches”, Journal of Management Studies, 43(1), 93-114.

\section{Forma de Citación}

MONFORT, Abel; SEBASTIÁN, Ana and LÓPEZ, Belén: Corporate identity in the brand co-creation era. Revista Communication Papers, $N^{\circ} 8$ (Monográfico II), páginas 31 a 40. Departamento de Filología y Comunicación de la Universidad de Girona. Recuperado el __ de___ de 2 de: http://www.communicationpapers.es 